\title{
Resistance of winter soft wheat varieties to leaf and yellow rust in the conditions of the Central Chernozem region of Russia
}

\author{
Yuliya V. Zeleneva ${ }^{*}$, and Ekaterina L. Shaydayuk \\ All-Russian Institute of Plant Protection, 196608 Saint Petersburg, Russia
}

\begin{abstract}
In 2020, resistance to leaf and yellow rust in 62 varieties of winter soft wheat recommended for cultivation in the Central Chernozem region of Russia was characterized. Varieties resistant to two rust species (group resistance) (16\%) or to one of them (18\% to yellow, $1 \%$ to leaf rust) have been identified. Moderate level of group resistance to both types of rust (disease severity up to $15 \%$ ) was shown for varieties Moskovskaya 56, Moskovskaya 70 and Latynevka. Varieties Bogdanka, Volzhskaya 100, Volzhskaya K, Izyuminka, Lidiya, Odesskaya 200, Rubin were characterized by moderate resistance to yellow rust and weak susceptibility to leaf rust. For the first time in the conditions of the Tambov region, the virulence of the yellow rust pathogen was studied, and racial composition was characterized. Two races 79E190 and 15E144 were revealed among Tambov isolates of $P$. striiformis by the use of a set of differential lines in the virulence analysis. All the isolates were avirulent to Avocet lines with genes $\operatorname{Yr} 5, \operatorname{Yr} 10, \operatorname{Yr} 12, \mathrm{Yr} 17, \mathrm{Yr} 24$ and $\mathrm{YrAR}$.
\end{abstract}

\section{Introduction}

Wheat is the main grain crop cultivated in the Central Chernozem region of Russia (CBSR). Disease damage is one of the factors limiting the yield of this crop. Leaf rust (causative agent Puccinia triticina) is the most common disease of wheat. In the conditions of the Chernozem region, the disease is observed annually and in some epiphytotic years can cause losses of $30-50 \%$ [1]. Stem ( $P$. graminis) and yellow rust (P. striiformis) are observed sporadically in the region in years with favorable weather conditions favorable for their development.

Cultivation of resistant varieties is an economically sound and environmentally safe method of protection against rust pathogens. In this regard, it is relevant to study promising wheat varieties for cultivation in the region on artificial infectious backgrounds for obtaining adequate results of immunological evaluation [2]. Such works are carried out annually in the Tambov region in the Central Russian branch of the "Federal Scientific Center named after I.V. Michurin". Information on the composition of regional pathogens populations is of particular importance to create creating an infectious background. As a result of population studies, it is has been shown that Tambov pathogen isolates do not

* Corresponding author: zelenewa@mail.ru 
differ significantly by virulence and racial composition on soft wheat from other European (from Central, Central Chernozem, North West region) and are also close in resemblance to North Caucasian ones $[2,3]$. Studies of the yellow rust pathogen racial composition in the CBSR have not been carried out to date. The purpose of this work was to assess the resistance to leaf and yellow rust in winter wheat varieties recommended for cultivation in the CBSR on the infectious plot of the Central Russian branch "FSC named after I.V. Michurin", as well as the virulence analysis of the causative agent of yellow wheat rust.

\section{Materials and methods}

The research material contained 62 varieties of soft winter wheat.

In general, the weather conditions of the 2020 growing period differed from the perennial averages (Table 1).

Table 1. Meteorological conditions of the 2020 growing season (according to the Tambov CGMS branch of FSBI "Tsentralno-Chernozemnoe UGMS")

\begin{tabular}{|c|c|c|c|c|c|c|}
\hline \multirow{2}{*}{ Indicator } & \multirow{2}{*}{ Decade } & \multicolumn{5}{|c|}{ Months } \\
\hline & & April & May & June & July & August \\
\hline $\begin{array}{l}\text { Average monthly air } \\
\text { temperature, }{ }^{\circ} \mathrm{C}\end{array}$ & - & 6.0 & 12.7 & 19.9 & 20.8 & 19.0 \\
\hline $\begin{array}{l}\text { Maximum air } \\
\text { temperature, }{ }^{\circ} \mathrm{C}\end{array}$ & - & 21.4 & 27.4 & 31.0 & 35.3 & 32.6 \\
\hline $\begin{array}{l}\text { Minimum air } \\
\text { temperature, }{ }^{\circ} \mathrm{C}\end{array}$ & - & -7.4 & 2.1 & 9.5 & 8.6 & 14.3 \\
\hline $\begin{array}{l}\text { Average perennial } \\
\text { average monthly air } \\
\text { temperature, }{ }^{\circ} \mathrm{C}\end{array}$ & - & 6.8 & 14.5 & 18 & 19.4 & 18.1 \\
\hline \multirow{5}{*}{$\begin{array}{l}\text { Precipitation by } \\
\text { decades, } \mathrm{mm}\end{array}$} & $\mathrm{I}$ & 2 & 38.5 & 61.8 & 33.2 & 3.1 \\
\hline & II & 21 & 17.2 & 0.6 & 2.3 & 8.6 \\
\hline & III & 4.5 & 16.5 & 43.0 & 10.5 & 4.0 \\
\hline & $\sum$ & 27.5 & 72.2 & 105.4 & 46.0 & 15.7 \\
\hline & $\begin{array}{c}\text { Perennial } \\
\text { average }\end{array}$ & 37 & 52 & 56 & 70 & 60 \\
\hline \multirow{5}{*}{ Relative humidity, $\%$} & $\mathrm{I}$ & 43 & 62 & 71 & 63 & 57 \\
\hline & II & 61 & 60 & 54 & 63 & 61 \\
\hline & III & 51.8 & 65 & 63 & 54 & 55 \\
\hline & Average & 52 & 62 & 63 & 60 & 57 \\
\hline & $\begin{array}{c}\text { Perennial } \\
\text { average }\end{array}$ & 74 & 62 & 63 & 68 & 69 \\
\hline
\end{tabular}

The average monthly air temperature in April was $6.0^{\circ} \mathrm{C}$, which is $0.8^{\circ} \mathrm{C}$ higher than normal. The precipitation amount for the month was $27 \mathrm{~mm}$, this amount corresponds to $74 \%$ of the norm.

During the first decade of May, the average air temperature amounted to was $13.9^{\circ} \mathrm{C}$, which is $1.1^{\circ} \mathrm{C}$ higher than normal. At the same time, the maximum temperature was from $15.1^{\circ} \mathrm{C}$ to $26.5^{\circ} \mathrm{C}$, and the minimum $-4.1-14.7^{\circ} \mathrm{C}$. The total amount of precipitations for the decade was $38.5 \mathrm{~mm}$ (226\% of the norm for the decade): there were three days for in the decade with precipitations of more than $5 \mathrm{~mm}$ (6, 8, 10 May). The average relative humidity was $62 \%$.

The average air temperature for in June was in around $19.9^{\circ} \mathrm{C}$ (1.9 deviation from the 
norm). The absolute maximum temperature for the month was $31^{\circ} \mathrm{C}$, the absolute minimum of air temperature was $9.5^{\circ} \mathrm{C}$. The month's precipitation amount was $105.4 \mathrm{~mm}$ (188\% normal for the month).

Those were the exact weather conditions that allowed the pathogen P. striiformis to infect winter wheat crops and cause wheat yellow rust disease in the region. In 2020, high development of yellow rust was observed in the Tambov region. The disease development on susceptible varieties reached $70 \%$. This allowed to conduct a qualitative assessment of the wheat varieties resistance to $P$. striiformis.

The assessment of resistance to leaf rust was carried out on an artificial infectious background. Plants' spraying was implemented during the booting stage using an aqueous suspension of leaf rust spores with the addition of Twin 80 detergent. After inoculation, the plots were covered with polyethylene film for 16-18 hours. Urediniospores of the collective Tambov population $P$. triticina were used as an inoculum.

Disease severity (\%) and type of reaction (score) were used to assess resistance. The intensity of leaf rust severity was assessed according to the Peterson et al. scale, yellow the modified Cobb scale. The type of reaction to leaf rust was determined according to Mains and Jackson scale, and to yellow rust - to Gassner and Straib [4]. Wheat varieties affected from 0 to $1 \%$ were categorized as immune; $1-5 \%$ - resistant; $5-15 \%$ - moderately resistant; $15-25 \%$ - moderately susceptible; $25-40 \%$ - susceptible; $>40 \%$ - highly susceptible. Plants with type of reaction scores 0,$0 ; 1(\mathrm{R})$ were classified as highly resistant, with score 2 (MR) - as moderate resistant, with scores of 2-3, X - as moderately susceptible (MS), 4 - highly susceptible (S).

To study the racial composition of yellow rust pathogen populations, leaves with urediniopustule were collected on the highly susceptible variety Basalt in the period of maximum disease development. Multiplication of infectious material, cloning and virulence analysis were carried out according to the previously described methods $[5,6]$. The virulence analysis of yellow rust pathogen was carried out using international and European differential sets (Chinese $166(Y r 1)$, Lee (Yr7, Yr22, Yr23), Heines Kolben (Yr6), Vilmorin 23 (Yr3a), Moro (Yr10), Strubes Dickkopf, Suwon 92/Omar / Hybrid 46 (Yr3b, Yr4b), Reichersberg 42 (Yr7), Heines Peko, Nord Desprez (Yr3a), Compair (Yr8), Carstens V, Spaldings Prolific, Heines VII (Yr2)) and Avocet (Ac) isogenic lines with genes $Y r 1, Y r 5$, $\operatorname{Yr6}, \operatorname{Yr} 7, \operatorname{Yr} 8, \operatorname{Yr}$ 9, $\operatorname{Yr10}, \operatorname{Yr11}, \operatorname{Yr12}, \operatorname{Yr15}, \operatorname{Yr17}, \operatorname{Yr} 18, \operatorname{Yr24}, \operatorname{Yr} 26, \operatorname{YrSk}(27), \operatorname{YrAR}, \operatorname{YrSp}$ [7].

Statistical analysis was carried out using the computer program "StatSoft STATISTICA $10 "$.

\section{Results and discussion}

In the conditions of artificial infectious background, high severity of leaf rust was observed in Tambov region in 2020. The susceptible standard variety Myronovskaya 808 was $90 \%$ affected. The severity of yellow rust was lower. The maximum disease severity on susceptible varieties achieved to $70 \%$.

There were no highly immune winter wheat varieties (disease severity $0 \%$ ) in the field. Varieties with group resistance to both rusts are of particular value for farming. Moderate level of group resistance to both rusts (diseases severity up to $15 \%$ ) had varieties Moskovskaya 56, Moskovskaya 70 and Latynevka. The results of phytopathological evaluation for other varieties are presented in table 2 . 
Table 2. Immunological characteristics of soft winter wheat varieties for rust resistance

\begin{tabular}{|c|c|c|}
\hline \multirow[t]{2}{*}{ Variety } & \multicolumn{2}{|c|}{$\begin{array}{l}\text { Disease severity }(\%) \text { and } \\
\text { type of reaction }\end{array}$} \\
\hline & P. triticina & P. striiformis \\
\hline \multicolumn{3}{|c|}{ Varieties with group resistance to leaf and yellow rust } \\
\hline Moskovskaya 56, Moskovskaya 70, Latynivka & $5-15 \mathrm{~S}$ & $5-15 \mathrm{MR}$ \\
\hline $\begin{array}{l}\text { Bogdanka, Volzhskaya 100, Volzhskaya K, Izyuminka, Lydia, Rubin, } \\
\text { Odessa } 200\end{array}$ & $15-25 \mathrm{MS}$ & $5-15 \mathrm{MR}$ \\
\hline \multicolumn{3}{|l|}{ Yellow rust resistant varieties } \\
\hline Kryzhinka, Inna, L'govskaya 167 & $25-40 \mathrm{~S}$ & $1-5 \mathrm{R}$ \\
\hline $\begin{array}{l}\text { Augusta, Antonivka, Belgorodskaya 12, Basalt, Mironovskaya 100, } \\
\text { Donskaya lira, Donskaya bezostaya, Moskovskaya } 39\end{array}$ & $25-40 \mathrm{~S}$ & $5-15 \mathrm{MR}$ \\
\hline \multicolumn{3}{|l|}{ Leaf rust resistant varieties } \\
\hline Tarasovskaya 97 & $5-15 \% \mathrm{MR}$ & $25-40 \% \mathrm{~S}$ \\
\hline \multicolumn{3}{|l|}{ Receptive varieties } \\
\hline $\begin{array}{l}\text { Odesskaya 267, Almira, Gubernator Dona, Don 93, Doneko, Selyanka, } \\
\text { Skipetr, Sloboda, Spartak }\end{array}$ & $25-40 \mathrm{~S}$ & $15-25 \mathrm{MS}$ \\
\hline Ermak, Cruiz, Sintetik & $15-25 \mathrm{MS}$ & $25-40 \mathrm{~S}$ \\
\hline $\begin{array}{l}\text { Bezenchukskaya 380, Don 85, Donskoy surpriz, Korochanka, Kosovitsa, } \\
\text { Laguna, Mironovskaya } 65\end{array}$ & $25-40 \mathrm{~S}$ & $25-40 \mathrm{~S}$ \\
\hline Biryuza, Zvonnitsa, Kalach, List 25, Ariadna & $>40 \mathrm{SS}$ & $25-40 \mathrm{~S}$ \\
\hline $\begin{array}{l}\text { Belgorodskaya 16, Zarya, L'govskaya 4, Mironovskaya 808, Prestizh, } \\
\text { Povolzhskaya } 86 \text {, Severodonetskaya yubileynaya, Surava, Smuglyanka, } \\
\text { Tarasovskaya 24, Tarasovskaya 29, Chervonnaya, Chernozemka 115, } \\
\text { Chernozemka 212, Chernozemka 88, Epokha odes'ka }\end{array}$ & $>40 \mathrm{SS}$ & $>40 \mathrm{SS}$ \\
\hline
\end{tabular}

Varieties Bogdanka, Volzhskaya 100, Volzhskaya K, Izyuminka, Lidiya, Odesskaya 200, Rubin were characterized by moderate resistance to yellow rust and weak susceptibility to leaf rust. High levels of resistance to yellow rust were shown by varieties Kryzhinka; Inna; L'govskaya 167; moderately resistant - Avgusta, Antonivka, Belgorodskaya 12, Mironovskaya 100, Donskaya lira, Basalt, Donskaya bezostaya and Moskovskaya 39. The number of leaf rust resistant varieties in the field was lower. Only on the Tarasovskaya 97 variety, the disease severity did not exceed $15 \%$. All other varieties were characterized by varying degrees of susceptibility.

As a result of the field assessment to leaf and yellow rust, $4.8 \%$ of varieties with moderate level of group resistance to both rust species were identified; $11.3 \%$ of varieties were moderately resistant to yellow rust and weakly susceptible to leaf rust; $18 \%$ - resistant to yellow rust and $1 \%$ - resistant to leaf rust

According to the literature data, the studied varieties lack highly effective genes of resistance to leaf rust ( $L r$-genes) [8]. At the same time, they have high representation of gene Lr34, which belongs to a group of genes that provide quantitative resistance (syn. partial resistance, slow rusting resistance) [9]. The Same cluster with $\operatorname{Lr} 34$ gene contains a yellow rust resistance gene $\operatorname{Yr} 18$. Among the studied wheat material, $\operatorname{Lr} 34 / \mathrm{Yr} 18$ genes have the varieties Izyuminka, Lidiya, Odesskaya 200, Antonivka, Donskaya lira, Donskaya bezostaya, Latynevka and Bogdanka. The Bogdanka variety additionally contains rye translocation 1AL.1RS with unidentified resistance genes of resistance to leaf and stem rust [10].

In these studies, most of the studied varieties with the $\operatorname{Yr} 18$ gene were characterized by varying degrees of resistance to yellow rust in the CBSR field conditions. Efficiency of Lr34 gene in protection against leaf rust was lower. In Russia, the Lr34 gene began has started losing its effectiveness since 1970 in the North Caucasus, where varieties with it began to be widely cultivated. At the same time, it remains effective in other countries of the world [11]. 
Using a set of differential lines two races of $P$. striiformis (79E190 and 15E144) were revealed in virulence studies . One of them was avirulent to varieties Moro ( $\mathrm{rr} 10)$, Strubes Dickkopf, Hybrid 46, Spaldings Prolific, Heines VII, and another one - to Moro, Strubes Dickkopf, Suwon 92/Omar, Hybrid 46, Reichersberg 42, Heines Peko, Nord Desprez and Carstens V. All the P. striiformis isolates were avirulent to Avocet lines with genes $Y r 5$, $\operatorname{Yr10}, \operatorname{Yr} 12, \operatorname{Yr} 17, \operatorname{Yr} 24$ and $\operatorname{YrAR}$. Variation between isolates for virulence was observed on lines with genes $Y r 7$ and $Y r 15$. Susceptibility reaction to other $Y r$-genes was observed. P. striiformis races found on soft wheat in the Tambov population in 2020 were different from those identified in Krasnodar, Leningrad and Novosibirsk populations in 2019 [5].

\section{Conclusion}

In these studies performed in 2020 in the field conditions of the Tambov region, the resistance to leaf and yellow rust in 62 varieties of soft winter wheat recommended for cultivation in the Central Chernozem region was studied. Perspective material of winter wheat resistant to two rust species (group resistance) (16\% of studied varieties) and to one of them ( $18 \%$ - yellow, $1 \%$ - leaf rust) was revealed. The widespread cultivation of resistant varieties will contribute to effective genetic protection of wheat from rust and stabilize the phytosanitary situation in the region. For the first time in the conditions of Tambov region, the virulence of the yellow rust pathogen was studied, racial composition was characterized and comparative analysis with other regional populations (North Caucasian, North West, West Siberian) was performed. Thus, preliminary data for 2020 have been obtained and in the future, the research will continue.

\section{Acknowledgements}

The current research for yellow rust pathogen was supported by RSF grant No. 19-7630005 .

\section{References}

1. Y.V. Zeleneva, Abstract of a thesis of Doctor of Biology, 41 (2019).

2. J.A. Kolmer, M.G. Kabdulova, M.A. Mustafina, N.S. Zhemchuzhina, V. Dubovoy, Plant Pathology, 64, 328 (2015)

3. E.I. Gultyaeva, E.L. Shaydayuk, E.G. Kosman, Plant Pathology, 69, 860 (2020)

4. R.A. McIntosh, C.R. Wellings, R.F. Park, Wheat rusts. An atlas of resistance genes (CSIRO Australia, Kluwer Acad. Publ., Dordrecht, the Netherlands, 1995)

5. E.I. Gultyaeva, E.L. Shaydayuk, Mikologia I Fitopatologiya, 54, 299 (2020)

6. P. Cheng, X.M. Chen, Phytopathology, 104, 1210 (2014)

7. R.E. Amil, S. Ali, B. Bahri, M. Leconte, C. Vallavieille-Pope, K. Nazar, Plant Pathology, 69, 618 (2020)

8. E.I. Gultyaeva, BIO Web of Conferences, 13 (2020)

9. E.S. Lagudah, H. McFadden, R.P. Singh, J. Huerta-Espino, H.S. Bariana, W. Spielmeyer, Theor Appl Genet, 114, 21 (2006)

10. E.I. Gultyaeva, Genetic structure of Puccinia triticina populations in Russia and its variability under the influence of host plant (Doctor biol. Thesis. Pushkin-St. Petersburg, Russia: All-Russian Institute of Plant Protection. 2018) 
11. S.G. Krattinger, E.S. Lagudah, T. Wicker, J.M. Risk, A.R. Ashton, L.L. Selter, T. Matsumoto, Plant J. 65, 392 (2011) 